\title{
The Application of Han Embroidery Art in Modern Fashion Design Chen-Xu ZHONG ${ }^{1, a}$, Hong-Guang YE ${ }^{1, b^{*}}$ \\ ${ }^{1}$ College of Fashion, Wuhan Textile University, Wuhan, 430073, China \\ a353092735@qq.com, b836001463@qq.com
}

Keywords: Han embroidery, background and development status, artistic features, costume design.

\begin{abstract}
Han embroidery is a kind of regional embroidery with Hubei characteristics, which contains the profound artistic connotation over the development of thousands of years. Today, more emphasis is put on traditional handicrafts .Han embroidery has been protected in time as an indispensable pat of Chinese traditional culture. This article starts with the historical background and the present situation of the development of Chinese embroidery, and discusses its artistic features, innovative two aspects of the way of thinking, the application of Chinese embroidery art in modern dress design.
\end{abstract}

\section{Introduction}

Embroidery has a long history in China, not only including the world-renowned "four famous embroideries", but also a variety of other regional embroidery. In the art of embroidery, Han Embroidery seems insignificant and nobody cares. Until February 2008, when Han Embroidery was included in the national intangible cultural heritage list, its mysterious veil was gradually lifted, it is refreshing [1] It combines practicality and artistry in one, deeply loved by the majority of the people, but this traditional handicraft is facing the problem of transformation to the modern industry. This article is taking about how to retain the essence of Han embroidery art and how to use it in modern dress rationally, in order better develop the intangible cultural heritage-Han Embroidery, so as to better protect and inherit it.

\section{Discussions and Analyses}

\section{Historical Background and Development Status of Han Embroidery}

\section{Historical Background}

Han Embroidery grew in Jingchu earth, deeply influenced by Chu culture and Chu embroidery .It develops with the development of Chinese embroidery. Embroidery throughout the country generally developed in the Ming Dynasty, and the characteristics of the territory of the embroidered appeared in the Qing Dynasty and identified a clear position. At this time Jingsha area appeared some embroidery-based workshops, mainly engaged in embroidered wedding funeral gifts, seasonal ornaments, temple sacrifice, clothing, bedding, table chairs and the other supplies. Since then, the local drama line head was regarded as an important content of the embroidery, the Jingsha Han opera with the first line of the head came to Hankou town and in Hankou town it has been rapidly developed, forming the Embroidered Street. But because of the war and other reasons Hankou artists drift diffused out of the field, so that embroidery has been more widely disseminated in the province, embroidered art has spread to Hankou, Yichang, Xiangfan and other places, and finally returned to Jingsha. So the embroidery, the regional embroidery, is centered by Jingsha, Wuhan, and Honghu.Jingsha area is the origin of embroidery, Wuhan area is the main origin of embroidery Honghu area is the diversion of embroidery.

\section{Development Status}

With the constant development of society, the traditional Han embroidery handicraft is slowly forgotten. Now people who engaged in the work of embroidery only include Wuhan Han 
Embroidery Master Benrong Ren, Jingzhou Embroidery Master Xiansong Zhang and so on. The current Han embroidery products are single and too traditional, and also located in the primary stage of product development. But now, we are in such a stage, country promote cultural development and prosperity, the traditional handmade skills are attached importance once again. Embroidery return to everyone's vision as a national intangible cultural heritage. According to the author, in order to promote the art of embroidery, many schools set up a rhyme elective courses, such as Wuhan Textile University, Jingzhou Shashi Race Lane Primary School.

\section{The Artistic Features of Han Embroidery}

"Bold, bright and lively". This is the first visual perception of Han embroidery. In the formation and development process of Han embroidery, it relies on local secret agents ,and shows the rough and gorgeous art form, when you are far from it, it is magnificent when you are close to it, it looks delicate.

\section{"Flower without Fruition, Lively for the First" Design Features}

Design features is embroidery, which provides the basis for the Han embroidery. Han embroidery artists learn the essence of local folk embroidery in the creation process of embroidery, in order to realize the simple, plain and sincere artistic effect .So that this design features, aesthetics dominate the style of the screen.

\section{"Simple and Various, no Limit" Acupuncture Features}

Acupuncture features is a technology, it is the body of the embroidery. There is a large number of embroidery products discovered at Jiangling Mashan brick factory on the 1st Warring States Tomb unearthed during Warring States period, using the needle "braids"--a kind of acupuncture embroidery technique. "Braids" acupuncture is famous because its structural density has caused, and tracks are neat and plump. This kind of simple needle promotes the embroidery industry flourishing in Ancient Han. This feature is not only spread in the folk embroidery, modern Han embroidery also inherited the acupuncture, and make a further development creating other acupunctures. The improvement enriches the expressiveness of Han embroidery, and achieve the artistic effect. The myriads of changes exquisitely carved.

The skill of Han embroidery artists determines the grade of embroidery. At first, designers only need to determine the distribution of patterns on the embroidered surface, and outline the profile. Then it is the show time of designers by having the hierarchical embroidery on the rough surface. Han embroidery artists with tiling, pad, pressure, lock, buckle, plate and other simple needle to complete the complex pattern of characterization, aiming to achieving a multiplier effect.

\section{"Bright but not Vulgar, Vivid and Fresh" Color Features}

The color feature means the color of silk line, which is the appearance of Han embroidery .Color brings the first sensation to people, that visual effects even stronger than the shape. Jingchu folk is well known as "faraway look at color and near to see flowers", emphasizing the importance of color matching. ${ }^{[2]}$ Han embroidery goods are used in folk activities and folk life, including five categories: folklore, religion, comedy, daily necessities and decorative articles. Folk bright and simple way of color for the embroidery art played a critical role.

Han embroidery with respect to the color emphasizes the bright color, strong contrast, using complementary colors or contrasting colors to interpret the embroidery pattern, in order to make the bright saturation, visually beautiful decoration effect. Its embroidery is always backed with deep red,on top of that matching with other colorful colors and gold and silver side decoration to show some vibrant scene.

\section{The Application of Han Embroidery in Modern Dress}

Adding the Han embroidery elements in modern clothing reasonablly will be a new way of improving the decorative effect and value of clothing. Meanwhile it is also an important method to 
carry out the promotion of Han embroidery. The application of Han embroidery art in modern dress is divided into two parts: traditional application and innovation application.

\section{Traditional Application}

Traditional application means direct references, which applies the thousands year old original Han embroidery elements to modern dress design.

At the end of the twenty - second century to the beginning of the twenty - first century B.C. It had Dili Shun name Yu "Diao clothing embroidered clothes" said. The ancients wear short clothes and skirts. The first six chapters are clothes, and the last six chapters for the skirts. Above painting and below the embroidery. This is the famous emperor Dagon crown twelve chapter service system, opened in China's garment embroidery on the page. ${ }^{[3]}$

Chinese traditional design elements are mainly made up by the Royal aristocratic clothing on the pattern, folk paper-cut, embroidery and other patterns, the traditional ceramics and building window patterns, traditional auspicious animals ,plants, symbols and so on.

As can be seen from the above discussion, embroidery is a long history of art, which is definitely not an isolated development, but influenced by the mutual influence of sister art. Han embroidery in this area is more sensitive and broad, making it a unique type of regional embroidery. We will never ignore the study of other sister art when studying the Han embroidery, only in this way can we develop the Han embroidery into a more distinctive and more dynamic embroidery art.

\section{Innovation Application}

Innovation application means indirect references, which, to some extent, change the shape of traditional elements. But we can notice its source and meaning to fit different modern fashion styles and dress occasions. It is mainly manifested as the reconstruction, deformation, transformation, exaggeration, simplification of traditional elements, which weaken the traditional elements to highlight the cultural and artistic effects and other characteristics. ${ }^{[4]}$

\section{Application of New Materials.}

In the production and design process in modern clothing the dazzling array of new materials are used into the clothing industry which has injected a new design ideas, same as Han embroidery materials. In the past, most of the Han embroidery use silk as the main material, highlighting the performance of the embroidery texture through the different needle. Nowadays besides the traditional silk, people will create modern and fashion sense by matching with wool, blankets, beads, artificial feathers and other materials.

\section{Application of New Color.}

Traditional Han embroidery color mainly matched with bright and lively contrast colors. Modern clothing styles is variable, followed by the application of variable of color matching methods. Based on the style of dress it adjust the color of Han embroidery, such as hue, lightness, purity adjustment, the use of similar color scheme.

\section{Application of New DESIGN idea.}

In people's mind, the traditional Han embroidery appears in cheongsam dress frequently. Under the premise of keeping the traditional Han embroidery materials and colors, it can be applied to today's popular baseball clothing, jeans and other casual clothing, which will add luxury, the connotation of temperament.

\section{Conclusion}

The combination of tradition and innovation is the most important concept in Han embroidery development. This traditional crafts with a great local character, could be protected and deeply developed effectively by Chinese government with the help of thinking high of the east wind. It is an important method to promote the development of Han embroidery via using Han embroidery 
elements while opening up the space for the dress design. The author hopes that Han embroidery will get a better development in the bright and colorful art garden.

\section{References}

[1]Fen Zemin: Han Embroidery of Jingchu (Wuhan Publishing Press, China 2012)

[2]Chen Yuansheng, Li Yan: Han Embroidery Legend (Wuhan Publishing Press, China 2014)

[3]Wang Shizhu: The application of Su embroidery on clothing and artistic features (Guangxi light industry, China 2010).

[4]Peng Rong: Study on the application of Chinese traditional elements in Chinese brand clothing (Donghua University, China 2013). 